\title{
ПЕРЕКААДИ: ДОДАТКИ
}

\section{Олег Хома \\ КОМЕНТАР ДО УКРАЇНСЬКОГО ПЕРЕКЛАДУ «НАРИСІВ ПІРРОНІЗМУ» СЕКСТА ЕМПІРИКА (I, 1-13)}

Оскільки справа філософського перекладу повноцінно уможливилася в Україні лише після здобуття незалежності, протягом останніх десятиліть іде процес особливо інтенсивного термінотворення (а надто в перекладах з греки). Певна річ, цей процес далекий від завершення, деякі терміни швидко виходять $з$ ужитку, змінюючись на більш вдалі. Власне, ці коментарі слід розглядати саме як проміжний етап у виробленні термінологічної системи для відтворення українською творів Секста Емпірика ${ }^{1}$. Щодо деяких відповідників ще немає певності, їх може бути змінено при підготовці остаточної версії «Нарисів пірронізму». Загальні принципи перекладу цього твору викладені нижче (див. с. 93). Наразі ж ідеться про роз'яснення філософських підстав обрання українських відповідників деяких термінів Секста, найпроблемніших для відтворення. Виходячи з тези Барбари Касен про неперекладність філософських слів, ми вважаємо, що ця (доволі продуктивна) неперекладність має бути редукована до випадків справжньої неперекладності. Тобто, де це можливо $^{2}$, маємо зберігати парадигми оригінальних слів. Ці парадигми мають істотне філософське значення, оскільки вносять метафорику, надзвичайно важливу для розуміння змісту. Якщо цю метафорику заважають відтворити лише давні конвенції, ми воліємо йти за логікою лексичних ресурсів, не зупиняючись перед неологізмами.

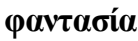

Проблемність перекладу цього терміна зумовлена усталеними варіантами його сприйняття, навіяними або російським (воображение / представление, відповідно: «уява / уявлення»), або англійським перекладами (impression, відповідно: «враження»). Звісно, грецьке $\varphi \alpha v \tau \alpha \sigma i ́ \alpha$ містить виразний момент пасивності, мимовільності тощо. До того ж, Ари-

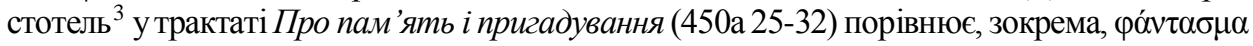

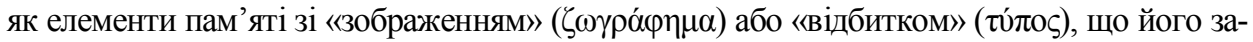

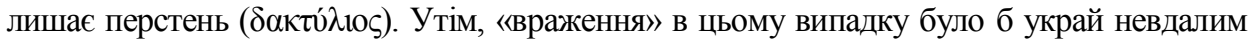
відповідником, і то з кількох причин.

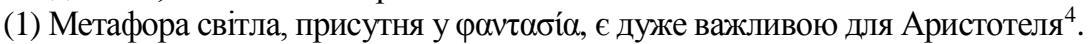

(C) О. Хома, 2020

${ }^{1}$ Про традицію засвоєння вчення Секста на Заході, див.: 「Bett 2011: 267-2871. - Також важливо розуміти, шо грунтовне знання традиції відкриває перспективу для найрізноманітніших ії контекстуалізацій. Наприклад, погане знання елліністичного контексту (отже, і скептицизму як його частини), унеможливлює спектр дотичних досліджень, як от, наприклад, [Blumenfeld 2003].

2 При перекладі «Нарисів пірронізму» враховувався досвід деяких перекладів цього тексту іншими мовами: лат., Анрі Етьєна [Sextus 1562]; англ., Джулії Енас [Sextus 2000]); англ., Роберта Бері [Sextus 2002]; іт., Онорато Тескарі [Sesto 1926]; рос., Надії Брюллової-Шаскольської [Секст

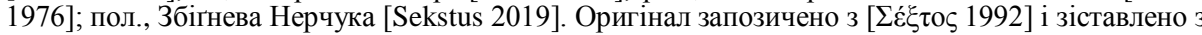
білінгвічним виданням [Sextus 2002]. На жаль, нам поки не вдалося знайти доволі новий франц. перекл. П'єра Пелегріна [див.: Масhuса 2002].

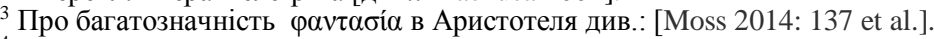

4 Див.: Про душу 429а 3-5. «Оскільки зір - найважливіше 3 чуттів, то своє ім'я воно [тобто

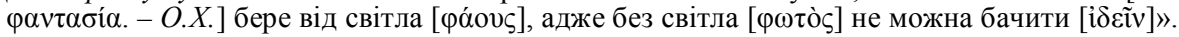


(2) Наприклад, російська традиція, що перекладає пару $ф \alpha v \tau \alpha \sigma i ́ \alpha-\varphi \alpha v \tau \alpha ́ \sigma \mu \alpha \tau о \varsigma$ як «во-

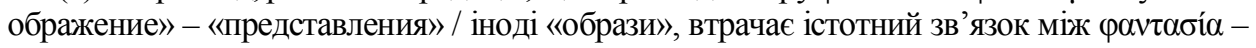

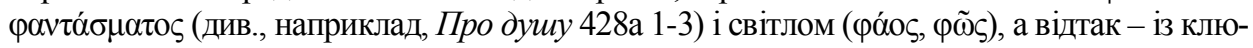

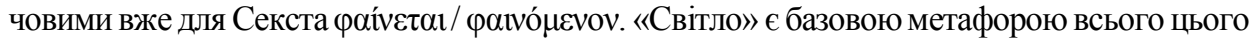
термінологічного ряду, а тому неабияк позначається на нашому розумінні того, що хотіли сказати Аристотель чи Секст, обираючи собі терміни.

Що Аристотелів, що Секстів ти́ло є є відбитком саме світла, а не чогось іншого, таким собі «світлописом», що постає і як фаıvó $\mu \varepsilon v o v$. Тому втрачати парадигматичний зв'язок між рить ${ }^{6}$. Але українська мова має унікальні лексичні ресурси для дуже точного відтво-

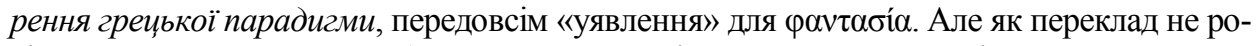

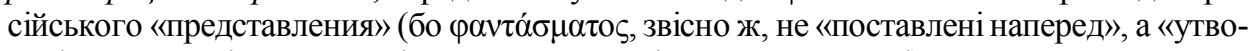
рені через висвітлювання» і згодом «записані» завдяки пам’яті), а саме грецького терміна. Корінь «яв-» чудово відтворює «світлову» парадигму, оскільки вказує і на «білий день» (=«світло»), і на «появу»/»постання», і на «явність», i, що найважливіше для творів Секста, на «явище»/《явлене». До речі, українське дієслово «уявляти» має застаріле значення «з'являтися», що чудово відбиває пасивні конотації $ф \alpha \nu \tau \alpha \sigma i ́ \alpha$. Коли ж остання вживається в сенсі «залежного від людської волі» (Аристотель, Про душу 427b 17-18), «уявляти» чудово відтворює і цей аспект.

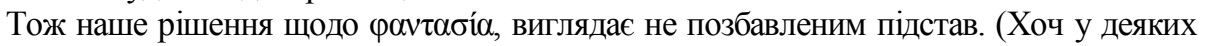
контекстах неминучим є відповідник «виображення»). Воно добре працює й у випадку

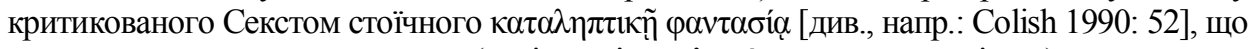

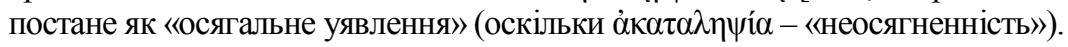

\section{$\pi \alpha ́ \theta 0 \varsigma$}

Принцип уникнення латинізмів створює неабиякі проблеми при перекладі та́ $\theta$ os. Зазвичай це деякий «стан», що передбачає мимовільність (див. прим. 5), тобто «пасивність». Сама суть скептичного підходу виражається через витлумачення скептикового patvó $\mu \varepsilon v o v$ як його власного (

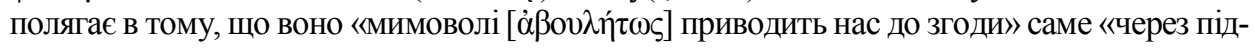

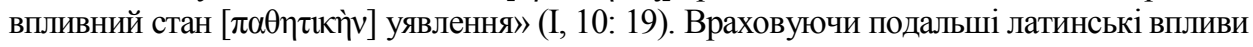
на словник західної філософії, ідеться, безперечно, про проблему «пасій», які в нас частіше називають «пристрастями» ${ }^{7}$. Утім, українське «пристрасть» передовсім вказує на збурення, а не на «неактивність». Натомість іменник «пасія», який вказує на те, що тебе охоплює й тобою не контролюється - латинізм. Тому в описаному щойно провідному зна-

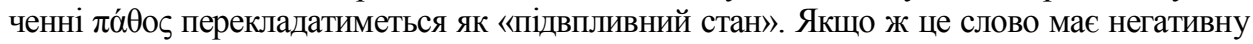
конотацію (голод, спрага), буде природно перекласти його як «потерпання».

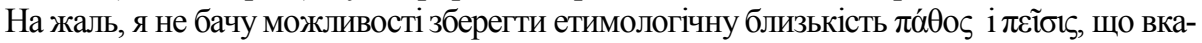
зує на «[душевне] хвилювання» (див. прим. 5). Тут доведеться обмежитися контекстним пе-

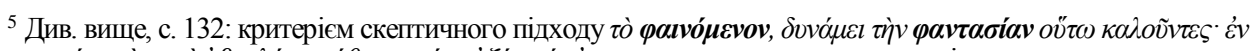

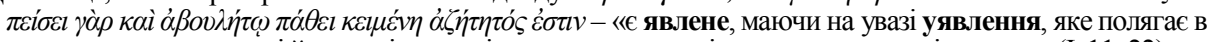
душевному хвилюванні й мимовільних підвпливних станах і яке не улягає дослідженню» (I, 11:22).

${ }^{6}$ У І книзі трактату Проти логіків Секст активно покликається на стоїчне уподібнення фаvтабі́ і ти́лос. Див.,

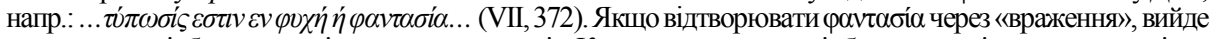
«враження є відбиток в душі», ледь не тавтологія. Коли ж «уявлення є відбиток в душі», туг маємо плідне твердження про світловий вплив, що лишає відбитки. Змістовність цих фраз $є$ незіставною!

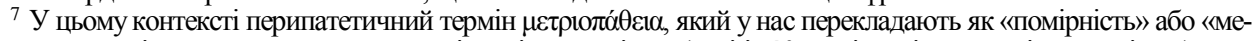

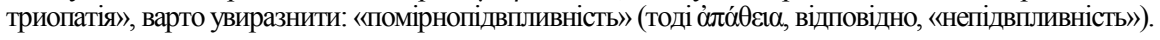


рекладом і коментарем. Узагалі, надто принципово дотримана відмова від латинізмів яскраво увиразнює всю глибину залежності нашої філософської мови від останніх. Тому, мабуть, із цього принципу варто зробити деякі винятки (наприклад, для и̌ $\eta$, «матерія»).

Зрештою, досвід перекладання «Нарисів пірронізму» засвідчив як складність роботи за відсутності усталеної традиції, так і плідність лексичних ресурсів «ще однієї» філософської мови для української термінології.

\section{СПИСОК ЛІТЕРАТУРИ / REFERENCES}

Bett, R. (2011). The Cambridge Companion to Ancient Scepticism. Cambridge: Cambridge University Press. https://doi.org/10.1017/CCOL9780521874762

Blumenfeld, B. (2003). The Political Paul: Democracy and Kingship in Paul's Thought. London, \& New York: T \& T Clark.

Colish, M. (1990). The Stoic Tradition from Antiquity to the Early Middle Ages (Vol. 1). Leiden : Brill.

Machuca, D. E. (2002). Sextus Empiricus, Esquisses pyrrhoniennes. Introduction, traduction et commentaires par Pierre Pellegrin [compte-rendu]. Revue Philosophique de Louvain, 100(4), 797-801.

Moss, J. (2014). Aristotle on the Apparent Good: Perception, Phantasia, Thought, and Desire. Oxford: Oxford University Press.

Sekstus Empiryk. (2019). Zarysy Pyrrońskie. (Z. Nerczuk, Ed. \& Trans.). Toruń: Wydawnictwo Naukowe UMK. Sesto Empirico. (1926). Schizzi pirroniani. (O. Tescari, Trans.). Bari: Laterza.

Sextus Empiricus. (1562). Pyrrhoniarum hipotyposeon libri tres. (H. Stephanus, Trans.). Parisiis: M. Iuuenem. Sextus Empiricus. (1976). Three books of the Pyrrhonic principes. [In Russian]. In Sextus Empiricus, Collected works, in 2 vol. (Vol. 2, pp. 207-380). Moscow: Mysl.

Sextus Empiricus. (1992). Outlines of Pyrrhonism. [In Greek]. Athens: Cactus.

Sextus Empiricus. (2000). Outlines of Scepticism. (J. Annas \& J. Barnes, Eds.). Cambridge: Cambridge UP. Sextus Empiricus. (2002). Outlines of Pyrrhonism. (R. G. Bury, Ed.). Cambridge Mass.: Harvard UP.

Одержано / Received 12.09.2020

\section{Oleg Khoma}

\section{Commentary on the Ukrainian translation of Sextus Empiricus' Outlines of Pyrrhonism (I, 1-13)}

Some terms from Outlines of Pyrrhonism (I: 1-13) are problematic for Ukrainian translation. The commentary justifies the Ukrainian equivalents for those terms, in particular, "uyavlennia" for phantasia (not “vrazhennia”!), “pidvplyvnyi stan” for pathos (not “prystrast”!), "pomirnopidvplyvnist” for metriopatheia, "neosiagnennist” for akatalepsia,

\section{олег Хома}

\section{Коментар до українського перекладу «Нарисів пірронізму» Секста Емпі- рика (I, 1-13)}

Деякі терміни «Нарисів пірронізму» (I, 1-13) є проблемними для українського перекладу. У коментарі обгрунтовано українські відповідники для цих термінів, зокрема «уявлення» для phantasia (не «враження»!), «підвпливний стан» (не «пристрасть»!) для pathos, «помірнопідвпливність» для metriopatheia, «неосягненність» для akatalepsia.

Oleg Khoma, Doctor of sciences in philosophy, Professor, Head of the Department of Philosophy and Humanities at Vinnitsia National Technical University.

Олег Хома, доктор філософських наук, завідувач кафедри філософії та гуманітарних наук Вінницького начіонального технічного університету.

e-mail:quid2anim@gmail.com 